Article

\title{
Exploring Factors Affecting Car Sharing Use Intention in the Southeast-Asia Region: A Case Study in Java, Indonesia
}

\author{
Yoon-Young Chun ${ }^{1, * \mathbb{D}}$, Mitsutaka Matsumoto ${ }^{2}$, Kiyotaka Tahara ${ }^{1}$, Kenichiro Chinen ${ }^{3}$ \\ and Hideki Endo ${ }^{4}$ \\ 1 Research Institute of Science for Safety and Sustainability, National Institute of Advanced Industrial Science \\ and Technology (AIST), 16-1 Onogawa, Tsukuba, Ibaraki 305-8569, Japan; k.tahara@aist.go.jp \\ 2 Advanced Manufacturing Research Institute, National Institute of Advanced Industrial Science and \\ Technology (AIST), 1-2-1 Namiki, Tsukuba, Ibaraki 305-8564, Japan; matsumoto-mi@aist.go.jp \\ 3 College of Business Administration, California State University, Sacramento, 6000 J Street, \\ Sacramento, CA 95819-6088, USA; chinenk@csus.edu \\ 4 Department of Economics, Nihon Fukushi University, 229 Kawaminami-shinden, Otamachi, Tokai, \\ Aichi 477-0031, Japan; endo@n-fukushi.ac.jp \\ * Correspondence: yy.chun@aist.go.jp; Tel.: +81-29-861-8868
}

Received: 1 August 2019; Accepted: 14 September 2019; Published: 18 September 2019

\begin{abstract}
This paper provides some insight into factors influencing the car sharing adoption and usage in Southeast-Asian developing countries like Indonesia, where car sharing is just emerging and so far, not effectively existent. This study uses an internet survey of 600 Indonesian respondents to examine how underlying factors, such as perceived benefits of car sharing related to convenience and cost-saving aspects, perceived risks and burdens of car ownership, and perceived values of car ownership as societal status can influence their intention to use car sharing. The results of the ordered logit models reveal that car sharing use intention is influenced by perceived benefits of car sharing and perceived values of car ownership as societal status. Among demographic attributes, income level has a positive effect on car sharing use intention. The implications and proper interpretations in the interplay among them can provide a useful guide to city transportation planners and business owners who attempt to promote car sharing schemes in the Southeast-Asian market like Indonesia.
\end{abstract}

Keywords: sharing economy; perceived benefits; psychosocial valuation; societal status; car ownership; ordered logit model; sustainable consumption and production; developing countries

\section{Introduction}

Car ownership levels are increasing rapidly in Southeast-Asian developing countries, especially in the larger cities [1,2]. There is generally a positive link between economic development and car ownership [3,4], thus the rapid income growth in developing economies enables motorization to quickly pick up the pace. Automobiles become more solidified in their positions as an increasingly attractive mode, and this automobile dependence will increase unless viable transportation alternatives are available [5]. Increased car dependency poses extensive environmental and social challenges, such as air pollution, greenhouse gas (GHG) emissions, traffic congestion and accidents, public human health, etc. Thus, designing a sustainable transportation system to help meet growing travel demand while reducing automobile dependence always remains on the city planner's task list.

Car sharing that has the potential to control vehicle ownership [6-8] is a model where users can rent cars on an hourly or daily basis. Car sharing is based on the concept of sharing the usage of a vehicle fleet by members for trip making on a per-trip basis [9]. Over the past decade, it has gained 
much attention among practitioners who see car sharing as a sustainable solution for transportation needs [10-12]. The primary benefits of car sharing include cost savings, compared to car ownership, and perceived environmental benefits [13]. Several studies have recognized that car sharing policies could lead particularly to the reduction of vehicle miles/kilometers traveled (VMT/VKT) and GHG emissions $[10,14-16]$.

Since 1998, when car sharing started to grow rapidly [17], car sharing has been operated in almost all European countries, North America, Australia, Japan, South Korea, and other countries including China as well. The number of carshare users in the world shows a growth trend that has increased from 0.35 million in 2006 to 5.29 million in 2014 [18]. Though car sharing activity is heavily concentrated in industrialized countries, there are currently a growing number of operations in developing countries [19]. With the increasing demand, especially from a fast-growing market like Southeast-Asian countries, the demand for better understanding and control of car sharing also increases.

It is uncertain whether the recent car sharing boom that has engulfed major developed cities could become an alternative mobility solution for developing economies as well, because the present trend shows that car sharing businesses are often struggling for profitability, even as membership increases over time [20]. This may depend on the overestimated (or underestimated) revenues of the services, mainly determined by the misunderstanding of users' behavior [20-22]. Thus, companies and authorities planning to use sharing schemes need to know users' intention and motives, and influential factors affecting users' behavior toward car sharing so that they can optimally position those in the scheme and maximize the benefits [6].

The objective of this study was to provide some insight into the use intention and affecting factors toward car sharing usage in Southeast-Asian developing countries. The focus of this study was on Indonesia as an example of an economically and demographically fast-paced growing country, especially among Southeast-Asian countries-including Thailand, Vietnam, Laos, Cambodia, Malaysia, and the Philippines. The research firstly performed semi-structured interviews with college students to explore their perception and to specify their motivation and potentially critical factors involved in the decision on car sharing usage. The interview took place not only in Indonesia, but in Thailand as well. This, though small sample sized and qualitative, could compare the opinions between them, thus allowing us to understand that their perception and motives on car sharing were often different, although some were in common. Then, this research structured the interview results to design survey questions and conduct an internet survey of 600 Indonesian respondents. The survey results identified the key elements of car sharing that most attract users, as well as those that could become barriers to use. Results were analyzed descriptively, and econometric analysis using ordered logit models was employed for exploring the car sharing use decisions of residents in Java, Indonesia. The findings from this analysis can contribute to the existing literature on the understanding of individuals' car travel behavior and factors affecting their intention to use car sharing in the Southeast-Asia region.

The rest of the paper is organized as follows. Section 2 defines the car sharing systems and Section 3 summarizes the analysis of the relevant literature reviews. Section 4 provides a brief introduction to the study areas and datasets obtained from interviews and the survey. The presentation of the semi-structured interview results is reported in Section 5. Section 6 focuses on the survey results, which illustrate the Indonesian respondents' awareness, perception, and intention of car sharing usage and highlights potential factors that might affect their intentions and behaviors. Section 7 reports the estimation results of a model that relates the intention to use car sharing to different variables (potential factors) and addresses the implications of the findings for transportation planning, policy, and business opportunities. Limitations of the study are also included in Section 7. The last section presents a summary of the research and concludes the article. 


\section{Car Sharing Systems}

Car sharing as a term is often used loosely, even for peer-to-peer (P2P) chauffeur/taxi services [19], but those P2P mobility services provided by Uber, Grab, Lyft, or Kakao T are ride-hailing services. Ride-sharing, traditionally referred to as carpooling, is also different from car sharing [23]. The key distinction between car sharing and ride-hailing or ride-sharing is that in car sharing systems, the shared vehicle is driven by the end-user, not a paid chauffeur. While carpoolers share car journeys together, with similar itineraries and time schedules in ride-sharing systems [23], the paid drivers of ride-hailing do not share the same destinations with passengers [24].

Car sharing systems can be classified with respect to depot location [25], trip configuration [26], and ownership, as shown in Figure 1. Depot location relates to the degree of freedom to place parking/depot stations in terms of service operators. As to the depot location, in other words, there are systems in which the available cars can only be parked at (generally small numbers of) designated stations, and other systems in which the cars can be freely parked in any legal on-street parking space or at any location in the owner's driveway. The former is often named station-based or stationary services. Based on the trip configuration, car sharing systems are divided into one-way and two-way (round-trip) systems [26]. Two-way (round-trip) systems require users to return the car to the same place that it was accessed [19]. One-way systems allow the users to pick up a car at a station and return it to a different station, introducing significant flexibility for users in terms of trip freedom, but complexities for system managers [27]. In relation to ownership, there are systems in which business companies or local/governmental authorities hold ownership of shared vehicles, referred to as business-to-consumer (B2C) car sharing [28]. Another is peer-to-peer (P2P) systems, in which the shared vehicles are owned by private individuals $[19,29]$. The latter is offered on consumer-to-consumer $(\mathrm{C} 2 \mathrm{C})$ market platforms.

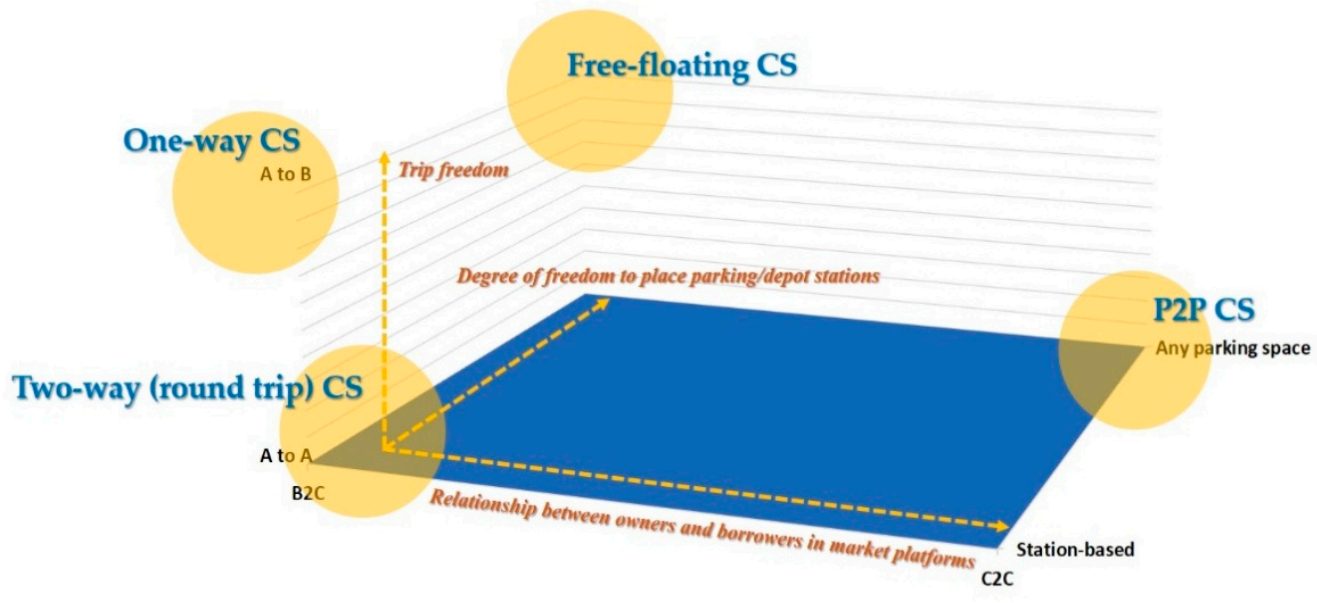

Figure 1. Classification of car sharing systems. Abbreviations: CS, car sharing; B2C, business-to-consumer; C2C, consumer-to-consumer; P2P, peer-to-peer.

\subsection{The Two-Way (Round-Trip) Car Sharing System}

The two-way (round-trip) car sharing system is a commercially well-established model [19], in which the journey must start and finish in the same place. The fleet for car sharing is centrally owned by operators, and parking/depot stations are managed by them as well. This system may easily plan vehicle inventories based on the demand [26], but it can be unattractive and inconvenient for users who need a vehicle for only one trip [30].

\subsection{The One-Way Car Sharing System}

The one-way car sharing system is similar to the two-way system, but users have more flexibility of returning the shared vehicle to a location of choice. In one-way systems, users are not obliged to 
drop off the vehicle to its original station. This system is unattractive for users who need a return, since they can be rejected for the return trip in the case that the inbound vehicle is assigned to another user who has reserved it in advance [30].

\subsection{The Peer-To-Peer Car Sharing System}

In the peer-to-peer (P2P) car sharing system, private persons decide to make their own car temporarily available for use by borrowers (users) and receive payments when the car is rented out $[19,29]$. Via the proliferation of the internet, smartphone technologies, and social networking applications, online organizations provide $\mathrm{C} 2 \mathrm{C}$ market platforms for effective matchmaking between car owners and prospective renters, facilitating car sharing [31]. Compared to other systems, P2P car sharing has more diversity of vehicles to select for users.

\subsection{The Free-Floating Car Sharing System}

The free-floating car sharing system allows users to pick up and drop off vehicles at any point and at any time within a specified area [11,32]. This system enables one-way journeys, in which the journey can start and finish in any place. The vehicles are generally owned by the system operator.

\section{Background Literature and Motivation}

\subsection{Existing Researches on Car Sharing Usage around the World}

The analyzed literature reviews of 20 references, mainly chosen from papers dated from 2001 to 2018 (last extraction of the database, October 2018) are summarized in Table A1 (in Appendix A). The scope of the literature review was focused mainly on car sharing cases. This study also included the cases investigating the effect of factors on car ownership decision if they targeted Asian developing countries. Hence, the selected researches indicate country- or region-specific case studies exploring usage motives and critical factors that might affect car sharing usage and related aspects of car ownership decision.

In comparison to the extent of research undertaken on individuals' perception and motives involved in car sharing adoption and usage in developed countries, less research is available for developing economies. Among the existing studies, the literature review found some studies exploring car ownership decisions in Southeast-Asian countries, where the upgrade process is recently witnessing that motorcycle owners are purchasing cars [1,33,34]. Noteworthily, Fukuda et al. [35] have conducted a study to investigate the possibility of car sharing application in Bangkok, among the highly-dense areas in Southeast-Asia. They discovered that socio-economic characteristics particularly, such as income, had a significant impact on an individual's mode choice, while service attributes such as accessibility, diverse vehicle options, technological assistance, and cost aspects had a strong influence on his/her perception of car sharing use. However, a brief summary of the relevant review studies suggests that there is still a dearth of knowledge about car travel behavior and related decisions in developing countries.

As shown in Table A1 in Appendix A, several case studies have targeted university students. Efthymiou et al. [6] descriptively analyzed the factors affecting sharing scheme adoption in Greece and they also focused on young adults. This might be attributed to the significance of the effect of the young generation's habits, perceptions, or beliefs on car travel behavior. Especially young travelers tend to be more flexible in travel behavior and to be less automobile-oriented [36]. This represents their great potential as prospective users.

Peer-to-peer (P2P) car sharing is an innovative approach, which allows a user to temporarily rent another person's (car owner's) car [29]. This approach is economically viable even in lower population-dense areas [37]. Ballús-Armet et al. [29] examined public perception and potential market segmentation of P2P car sharing in the San Francisco Bay Area, giving insights into the factors of joining 
P2P services. While previous studies provide us valuable insights into P2P car sharing operation, few have so far explained the propensity to join P2P services, especially in Southeast-Asian areas.

The present study contributes to the literature on individuals' behavioral intention and related aspects of car sharing use by presenting a case study from Java in Indonesia, while addressing the shortcomings of existing research highlighted in the foregone paragraphs. This study attempted to address the lack of existing research for Southeast-Asia developing countries; to target mainly the younger generation (but not limited by the online survey), and to cover individuals' intentions toward car sharing use, including the P2P type.

\subsection{Factors Influencing Car Sharing Use Intention Highlighted by Existing Studies}

The literature review of the relevant studies suggests that there can be many factors influencing a decision on car sharing use, but grouped mainly into socio-economic demographic characteristics and psychological factors as follows.

\subsubsection{Socio-Economic and Demographic Characteristics Affecting Car Sharing Usage}

Existing studies have observed socio-demographic variables as key drivers that help to increase the diffusion of car sharing services $[13,38]$. Demographic factors show the characteristics of a population expressed statistically such as age, gender, education level, income level, etc. Many studies have used socio-demographic variables to explain the propensity to join a car sharing model [6,38-41].

Car sharing choice appears to be driven by young adults, predominantly between the ages of 25 and $45[10,19,38,42]$. The younger generation's attitude and preference toward less auto-oriented transport $[36,43,44]$ suggest that car sharing is more prone to appeal to young adults.

People with a graduate level of education in the regions of North America and other developed cities appear to be more likely to choose a car sharing option $[38,39,45,46]$. On the other hand, one study suggests that the education level does not determine the possibility of becoming a car sharing member [47]. One reason that likely impacts the trend that car share members are more educated is the partnerships that many car sharing schemes have established with colleges and universities [39]. In developing countries like India, individuals who are qualified at or above the post-graduation level were found to be willing to buy a car sooner [34]. Thus, it is difficult in draw the conclusion that people with higher educational backgrounds in developing countries would choose to share a car instead of owning one.

Car sharing tends to be more popular among individuals with middle and lower incomes, to a certain extent $[6,10,17,40,46,47]$. However, some studies show that car share members tend to have skewed higher incomes [39,45]. Different income levels may define different motivations toward car sharing [45]. Hence, it is uncertain that car sharing schemes would be favored mostly by middle and lower income earners.

Users of round-trip car sharing tend to be living as single-person or childless couple households [19,45]. The results of Coll et al. [46] could temper those observations, by showing that the membership potential depended on the presence of children (positive), especially in single-parent families (positive). Individuals who come from car-owning families show a higher propensity not only to own a car [34], but also to choose to use car sharing sooner [35]. Individuals' lifestyles, in terms of frequency of car use, are significantly related to the probability of using shared vehicle services. Heavy users are generally more likely to join the services to satisfy their mobility needs [38].

A higher population density is conducive to an increase in car sharing activities [40], for high residential density is often closely connected with quality and availability of transit, a good pedestrian environment, and parking pressures—all representing success factors for car sharing [37,45,48]. The car sharing business model generally tends to work more effectively in highly-dense cities [39]. However, as highlighted by Hampshire et al. [37] in that P2P car sharing is economically viable to neighborhoods with lower population densities, car sharing business has become far from the geographical limitation in terms of high population density. 


\subsubsection{Psychological Factors Affecting Car Travel Behavior, Including Car Sharing Usage}

Travel behavior or transport mode choice is not only influenced by the utility of the transport system, but influenced by psychological factors [49]. Psychological factors may include perceptions, attitudes, and habits $[49,50]$. Existing studies have increasingly emphasized the role of psychosocial attributes such as social norms, culture, lifestyle, or habit in determining car ownership decision and choice of transport mode [34,51-53]. Psychological attributes have been found to have at least as much influence as demographic attributes on transport mode choice [54,55].

Especially, motives and perceptions are relevant in car sharing usage [41,56,57]. One's motives of value-seeking and convenience, affective or symbolic lifestyle, and altruistic environmental motives can influence his/her adoption and usage of car sharing [56]. Car sharing usage can also be positively influenced by ownership risk perceptions, further leading to the subsequent decision to reduce ownership [57].

In developing countries, attitudinal factors can significantly influence car travel behaviors such as car purchase or ownership decisions $[1,34,58,59]$. For instance, comfort-oriented attitude is associated with users' perception that a car is the most comfortable and safe mode of transport, or related to their belief that car traveling is less tiring. Those who are comfort-valuing appear to be more likely to own a car in India $[33,34]$. Independence-related aspects in terms of the car's time and space flexibility were also significant for students' decision to purchase a car in Indonesia [1].

Many existing studies have focused on real observed (observable) data on car sharing usage and related aspects, such as car ownership [7,10,40,60]. Investigating non-observable variables (attitudes, motives, and other psychological factors) can provide additional insights into the factors affecting car sharing usage [56].

\section{Materials and Methods}

\subsection{Methodological Framework}

Figure 2 depicts the flowchart of the methodological framework for this study. The preparatory research based on the comprehensive literature review conducted semi-structured interviews to specify potential critical factors influencing people's intention to use car sharing. Then, hypotheses were proposed to confirm whether those factors (exploratory variables) could positively or negatively influence one's intention toward car sharing usage. Using a dataset from the online survey, this study attempted to develop car sharing use intention models and to verify the hypotheses. Finally, the estimated results of the model were interpreted. The literature review has been discussed in detail earlier in Section 3. Semi-structured interviews, the survey, and statistical modeling analysis are further addressed in the subsequent sections.

\subsection{Qualitative Analysis with Semi-Structured Interviews}

Semi-structured interviews are a useful method for investigating the perceptions and opinions of respondents regarding complex issues, and they enable probing for more information and clarification on topics or an answer [61,62]. Specific topics or themes that an interviewer (investigator) likes to cover are provided, but open-ended questions are asked, thus ensuring flexibility [63]. This method allows the investigator to move from general topics to more specific factors and variables.

To obtain focused but qualitatively reliable data that can possibly become potential factors affecting an individual's intention or decision toward car sharing usage, the semi-structured interviews were performed in Thailand and Indonesia. The interviews focused on the college students at Kasetsart University located in Bangkok, Thailand and Muhammadiyah University located in Magelang, Indonesia. Five (5) and eleven (11) participants between the ages of 20 to 25 were interviewed on 9 and 12 July 2017 in Bangkok and Magelang, respectively. The interviews took $2 \mathrm{~h}$ each to complete and were fully transcribed. All interviews were conducted in English. 


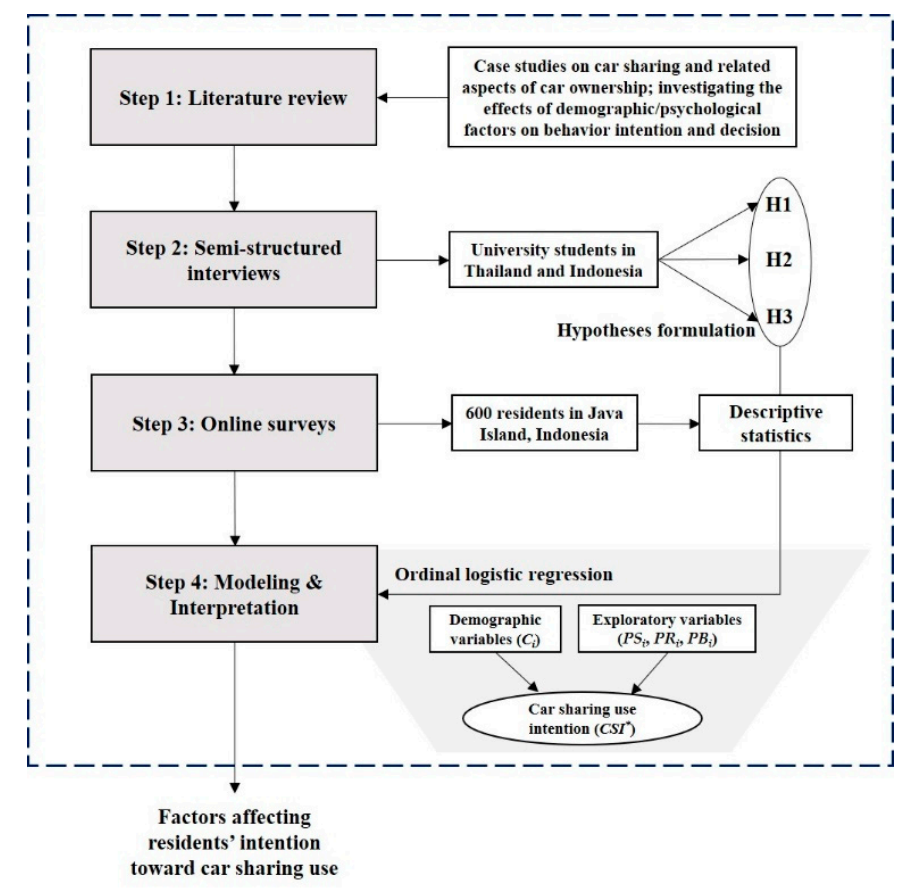

Figure 2. Methodological framework of this study.

Bangkok is the capital city of Thailand and it is served by many transport options, including rapid transit systems. Kasetsart University is in the neighborhood of office areas and commercial shopping districts in Bangkok. Students are exposed to automobiles and are familiar with road congestions. Motorcycles and public transportation, mainly buses, are the main transport modes for students.

Magelang is the capital city of Central Java Province and is one of the most densely populated areas in Central Java. Muhammadiyah University is close to the Magelang-Jogja highway. Students mainly use a motorcycle in daily activity, though public transportation such as buses and cars are operated in Magelang.

The interviews were structured in three parts (see Appendix B for more details). The first part included questions about the respondents' travel patterns and their satisfaction with the current travel, and their perception of advantages and disadvantages of car ownership. The second part gave a description of car sharing and asked their intention to use car sharing services. The third part invited opinions about the important factors when they decide to choose to use car sharing services. Based on the responses obtained from the interviews, hypotheses were proposed, as detailed in Section 5.4.

\subsection{Online Questionnaire Survey}

An online survey from 14 to 22 February 2019 was conducted by Cross Marketing Incorporation, the research agency we commissioned to carry out the fieldwork in Indonesia. A total of 600 complete and valid responses were received. The survey was controlled to require a sample of men and women who live in Java with a ratio of five to five. The gender distribution in the sample closely follows the gender distribution of the individuals who live in Java Island; males in each province and special region of Java Island ranged from 49.4 to 50.9\% [64], so the gender quota of 300 women and 300 men did not necessarily lead to significant bias. The geographical scope of this survey was an area of Java Island of Indonesia covering four administrative provinces such as West Java, Central Java, East Java, and Banten, and two special regions like Jakarta and Yogyakarta. Java Island is the political, economic, and cultural center of Indonesia, accounting for approximately $57 \%$ of the population of over 255 million in 2015 [65].

Indonesia has experienced a rapid increase in car ownership, like many other developing countries, reaching 79.6 cars/1000 people in 2013 (calculated based on $[66,67]$ ). The number of 
motorcycles still exceeds the number of cars, but the recent trend toward buying cars appears to be continuing [1]. Bus lines, including bus rapid transit (BRT) and four-wheeled minibuses or minivans (named Angkot), and taxis, including unofficial two-wheeled taxis (called Ojek), form the backbone of public transportation in Java areas.

The questionnaire mainly consisted of three categories of questions, demographic profiles of respondents, awareness, intention for using a car sharing, and possible influential factors for choosing to use a car sharing. Concretely, in the first category, the questionnaire asked for socio-demographic characteristics, including the household's car ownership status (e.g., the number of cars available, car registration history) and the individual's vehicle travel behavior (e.g., driving frequency of car or motorcycle). In the second category of the survey, the respondents were asked questions (statements) about their experiences toward car sharing, preference for car sharing types, and travel purpose (e.g., car sharing usage for travel, shopping, commuting, etc.). In the final category, statements related to respondents' intention to use car sharing services and their perception of car ownership and perceived benefits of car sharing were asked. The latter was to understand their usage motives, thus these possibly become factors for choosing a car sharing. The statements were taken from existing literature and adapted to the car sharing context (see Table A2 in Appendix $C$ for more details). They were also motivated by the findings from the semi-structured interviews.

The questionnaire was drafted in English, then translated to Indonesian for the survey. A total of 29 questions were used as closed-ended questions. Questions asking the intention of car sharing use and those asked to understand respondents' perception of related aspects of car sharing usage were based on a 7-point Likert scale, varying from strongly disagree (1) to strongly agree (7).

\subsection{Statistical Analysis}

This study includes a descriptive analysis, followed by an econometric model analysis based on the dataset obtained from the online questionnaire survey. The descriptive analysis summarized the dataset and, by employing appropriate statistical analysis, this led us to investigate the interplay among potential factors and car sharing decisions of the Java respondents. In our online survey, the respondents selected between an ordered seven (7) alternatives. An appropriate model for the analysis of the data on an ordinal scale is the ordered logit model [68]. The study used ordered logit models for a statistical method to examine the influence of the potential factors (identified from the semi-structured interviews) on the intention of Java residents to use car sharing.

In the ordered logit model, the dependent variable is treated as an unobserved, continuous latent variable $\left(Y^{*}\right)$, whose values determine what the observed ordinal variable $Y$ equals. The ordinal responses $j=1, . ., J$ represent measurements of this unknown latent variable, and $Y_{i}=j$ represents the ordered outcome for individual (respondent) $i$. This latent variable can be considered as utility, strength of preference, or opinion of the respondent about the subject in question [69]. The continuous latent variable $Y^{*}$ is determined by $J-1$ thresholds $\left(\mu_{1}, \ldots, \mu_{j-1}\right)$.

In the typical functional form of an ordered choice model [68], a latent variable $Y_{i}^{*}$ is introduced as:

$$
Y_{i}^{*}=\beta x_{i}+e_{i}, i=1, \ldots, n,
$$

where $\beta x_{i}$ represents the observable part and $e_{i}$ represents the unobservable error terms of respondent $i$ 's utility $Y_{i}^{*}$. The vector $x_{i}$ represents a set of $K$ explanatory variables that are assumed to be independent from $e_{i}$ and parameter vector $\beta$ represents the impact of explanatory variables.

According to Equation (1), this study developed ordered logit models to investigate the influence of a respondent's perceived values of car ownership related to societal status (PS), and related to risks and burdens $(P R)$ and their perceived benefits of car sharing related to convenience and cost-saving aspects $(P B)$ on the intention to use car sharing $(C S I)$, as follows:

$$
\mathrm{CSI}^{*}{ }_{i}=\gamma C_{i}+\delta P S_{i}+\theta P R_{i}+\tau P B_{i}+e_{i}
$$


where $\gamma$ is the vector of personal characteristics, $C_{i}$ is the vector representation of $i$ th respondent's personal characteristics (e.g., demographic attributes) adopted as control variable and $e_{i}$ is the error term.

The probability of a respondent choosing one of seven alternatives can be calculated based on the distribution of $e_{i}$. For the ordered logit models, the unobserved factors $e_{i}$ were considered random and assumed to follow a logistic distribution. Exploratory variables $(P S, P R$, and $P B$ ) were selected based on the results from the semi-structured interviews, as specifically described in Sections 5.4 and 7.2. Our main interest includes whether the signs of $\delta, \theta$, and $\tau$ support the hypotheses formulated in Section 5.4. As personal characteristics, the analysis used income. The income of the respondents was interpolated to the intermediate value of each range. Calculations and estimations were performed using IBM SPSS Statistics version 26 (IBM Corporation, Armonk, NY, USA), a software package for econometrics and statistics.

\section{Semi-Structured Interview Results}

\subsection{Current Travel Patterns and Their Satisfaction with Travel Modes}

The semi-structured interview results indicate that students in Bangkok and Magelang both mainly use a motorcycle in their daily lives, including commuting, due to the affordability of motorcycle. Students in Thailand appear to sometimes use a rental van service (with a paid driver) for short-term travel, while Indonesian students take a bus for visiting their parents or friends. Thai students said that they often drive their parent's car for a special occasion and in the rainy season. However, students in Indonesia tended to refrain from driving, no matter who they could borrow a car from, expressing their burdens and concerns about driving a car and other related aspects (e.g., accidents, maintenance, etc.).

Students in Thailand expressed a strong desire to use public transportation for commuting, but their satisfaction of using public transport, such as the metro or bus, for their trips to school was not so high. This was attributed to poor access, especially from home or school to the station. Indonesian students showed great satisfaction with the current mode, motorcycle, for any purpose except for a long journey. They perceived that a motorcycle allowed them to travel anytime to anywhere at a reasonable cost compared to a private car ownership or public transportation use.

\subsection{Perception about Advantages and Disadvantages of Car Ownership}

Respondents were not willing to buy a car soon in Indonesia, while those in Thailand expressed a strong desire to own a car if they can afford to. Young Indonesian respondents were concerned about the burden of ownership and considered this a disadvantage of car ownership. They perceived an owned car as an inconvenient mode in terms of maintenance, repair, and car accident management risks. This reveals that the perceived burdens of a private car ownership may affect their decision to forgo a car. This also can be linked to adopting car sharing services, where the service provider handles insurance, vehicle maintenance, and repairs as well.

To our knowledge, the climatic attribute has not been so far highlighted by existing studies. Respondents in Thailand showed a willingness to buy and drive a car, especially during the rainy season. This suggests that climatic attributes may influence a resident's desire or decision toward car usage, possibly leading to car sharing as well.

Students did not focus on the symbolic value of car ownership (e.g., cars are a status symbol, cars give an arrogant impression, etc.) as either an advantage or disadvantage, but some agreed that luxury and expensive car drivers look more successful in their careers.

\subsection{Car Sharing Use Intention and Influential Factors}

During the interviews, Thai respondents said among car sharing types, they would choose the one-way system and use for commuting. However, most respondents in Indonesia stated that they would prefer to use a two-way typed (a round-trip way) for visiting parents and friends during holidays. Convenience was chosen as the most important factor for the respondents, both in Thailand 
and Indonesia, when choosing the mode of transport and deciding to choose car sharing services as well. The perception of convenience for Thai respondents was flexible use, accessibility, connection with other transport modes, time-saving, etc. Indonesian respondents also mentioned convenience, but in terms of the reduced ownership' responsibility, and comfort and safe mode as the most significant criteria for car sharing usage.

\subsection{Hypotheses Formulation Based on the Semi-Structured Interview Results}

This study focused on several potential factors mentioned during the interview, formulating the hypotheses that those variables can positively or negatively influence individuals' intention to use car sharing in the Southeast-Asia region.

Perceived benefits are frequently used to understand a consumer's motives associated with attitude and behavior intention. The benefits of car sharing that might appeal to users are convenience aspects [56]. Convenience aspects like flexibility, time and effort savings on finding parking spots, and simple pricing systems have a positive effect on attitude toward car sharing services [21]. The semi-structured interview results also revealed that convenience was of importance as the main driver of deciding and choosing to use car sharing. Other benefits of car sharing may include the cost-saving advantages. Car sharing can be profitable for users who sometimes use a car for short trips [21]. It can provide users with monetary advantages compared to expenses of private car ownership [70]. Fukuda et al. [35] found that cost perception had a strong influence on the attractiveness of car sharing in Thailand. Considering that the affordability was the main reason for the respondents in Thailand and Indonesia for choosing a motorcycle as the current transport mode, the perceived cost savings of car sharing could thus influence their intention to use car sharing. Therefore, we hypothesized that:

H1. Perceived benefits of car sharing related to convenience and cost-saving aspects are positively related to car sharing use intention.

If an individual perceives car ownership to bear higher risk, this could increase an individual's usage of car sharing [57]. The higher perceived risk makes consumers need more information about a car so it can influence their decision to buy it, which possibly causes the consumers to cancel or delay their purchase. Instead, consumers are likely to choose to use car sharing. Many students in Indonesia opined that car owners suffer from the burdens of ownership and agreed that an owner's responsibilities of repair, maintenance, and replacement are important reasons for them to consider sharing a car instead of buying one (provided that a service provider handles these issues). Thus, this study proposed the following hypothesis:

H2. Perceived risks and burdens of car ownership are positively related to car sharing use intention.

Psychosocial valuation of a car is often a point of interest to understand an individual's behavior intention related to car ownership [59]. Perceived symbolic/affective values of a car, for instance, "cars bring prestige" or "cars allow to express oneself", may well be a driving force behind the intention to buy and own a car. Especially, many developing country case studies have investigated the effect of consumers' psychosocial valuation of a car-the symbol of success and status, on their purchase decision $[1,33,34,59]$. Shared vehicles are easily distinguished from private vehicles by a company mark or logo symbol. The higher one's perceived psychosocial utility of a car or car ownership related to status, he/she may not favor the shared car usage. Some students from the interviews gave a car symbolic images such as success and wealth. Hence, this study hypothesized that:

H3. Perceived values of car ownership as societal status are negatively related to car sharing use intention. 


\section{Survey Results}

\subsection{Demographic Profile of Respondents}

The demographic profile of the respondents obtained from the survey includes gender, age group, household's income range per year, household type, residential area, job (employment) status, and educational level (see for more details in Table A3 in Appendix D).

Of the total 600 respondents, $81.0 \%$ were in the age group of $20-39$ and $16.7 \%$ aged 40 to 49 years; the rest $(2.4 \%)$ were under 20 or over 50 . This shows that the respondents are mostly young adults. More specifically (see Table A4 in Appendix D), 19.5\%, 18.0\%, and 11\% of the total respondents were male in the age group of 20-29, 30-39, and $40-49$, respectively; $25.2 \%, 18.3 \%$, and $5.7 \%$ were female in the age group of $20-29,30-39$, and 40-49, respectively.

Of the respondents reported annual household incomes, 38.0\% were between IDR 60 and 119 million ( $=$ US\$4218-8370, IDR 100 thousand $=$ US\$7.03), while $18.0 \%$ reported they belonged to the income group of IDR 30-59 million ( $\fallingdotseq$ US\$2109-4150) per year. Of the respondents, $28.1 \%$ reported incomes of more than IDR 120 million ( $\leq$ US\$8440), which is generally categorized as high-income class in Indonesia. Median household income level was between IDR 60 and 89 million ( $=$ US\$4218-6260) per year in the sample, which appeared to be quite similar to KPMG's estimates [71]. While a high-income class consisting of households with annual incomes more than IDR 120 million accounted for $20 \%$ of the population [72] in Indonesia, the respondents were slightly overrepresented in the income groups of more than IDR 120 million.

Based on other profiles, such as household type, localization, job status, and educational level, the respondents were found to live with at least one other person $(73.4 \%$ of the total respondents; $64.7 \%$ lived with his/her children) in a relatively dense urban area ( $94.5 \%$ located in metropolitan center, metropolitan suburb, or local city area), having their own jobs ( $88 \%$ employed including self-employed individuals), and being well-educated (74.2\% with at least a bachelor's degree).

\subsection{Car Ownership and Vehicle Driving Frequency}

About $93.5 \%$ of the respondents have a license to drive a car, while $97.2 \%$ hold a motorcycle license. Furthermore, $96.4 \%$ of individuals in the sample own a car in his/her household, and nearly $19 \%$ own at least two cars in their house. This is much higher than the average vehicle ownership figure in Indonesia (87 Motor vehicles per 1000 people in Indonesia).

Among the respondents who own their cars, most of the cars have been owned for less than five, followed by five to nine years; thus, one can guess that car ownership phenomenon took place in the last 10 years. However, $10.1 \%$ of the respondents have owned their cars for between 10-20 years.

Looking at vehicle driving frequency, nearly $80 \%$ of the respondents drive a car at least three times a week, and $27.5 \%$ drive every day. Furthermore, $47.2 \%$ of the respondents drive a motorcycle every day, and $90.5 \%$ use a motorcycle at least three times a week. Respondents who drive a motorcycle or car less than three times a month accounted for $6.7 \%$ or $13.9 \%$ of the respondents, respectively.

More details are described in Table A3 in Appendix D.

\subsection{Awareness of Car Sharing and Related Experiences}

Respondents were asked to indicate whether they have ever heard of car sharing, in yes or no format. As shown in Table 1, the survey results represented that the majority $(70.3 \%, 422$ samples) of the 600 respondents had heard of car sharing. Of the 422 respondents who said they had heard of car sharing, $67.3 \%$ had also experienced using it. High awareness of car sharing may be attributed to 'Hipcar', which was launched as the first car sharing service specifically for Jakarta in Indonesia at the end of 2015. 
Table 1. Descriptive statistics of the survey.

\begin{tabular}{cc}
\hline Category & No. of Respondents ${ }^{1}$ \\
\hline Awareness of car sharing & $422(70.3)$ \\
Yes & $178(29.7)$ \\
\hline No & $284(67.3)$ \\
Experience of using car sharing ${ }^{2}$ & $138(32.7)$ \\
No & \\
\hline Choice of car sharing types & $207(34.5)$ \\
Two-way car sharing & $217(36.2)$ \\
One-way car sharing & $80(13.3)$ \\
Free-floating car sharing & $66(11.0)$ \\
Peer-to-peer car sharing & $30(5.0)$ \\
No type & \\
Trip purpose of car sharing & $425(70.8)$ \\
Travel & $149(24.8)$ \\
Shopping & $156(26.0)$ \\
Commuting & $141(23.5)$ \\
Business & $8(1.3)$ \\
Others & $600(100.0)$ \\
\hline Overall sample &
\end{tabular}

${ }^{1}$ Values in parentheses are the percentages of sample respondents. ${ }^{2}$ Values in parentheses are the percentages of sample respondents based on the respondents who have heard of car sharing (overall sample $=422$ ).

\subsection{Choice of Car Sharing Services—Preference for Types of Car Sharing}

The survey introduced a short description of car sharing services (see Appendix E). Respondents were then asked what type of car sharing service they would choose to use. As shown in Table 1, $36.2 \%$ of the respondents were interested in the one-way service, whereas $34.5 \%$ preferred to choose the two-way one. Of the respondents, $13.3 \%$ and $11.0 \%$ intended to use free-floating and P2P car sharing services, respectively. The remaining $5 \%$ showed no interest in any type. This suggests that the majority $(70.7 \%)$ of the Java respondents tend to prefer classic types of car sharing, which are station-based services, and this is in line with the findings from the semi-structured interview with the students.

\subsection{Trip Purpose of Car Sharing}

Respondents were asked to report all the different trip purposes they want to choose by using car sharing. They mostly wanted to use car sharing services for traveling, and the percentage of respondents using car sharing for purposes (multiple responses permitted) were: Traveling, 70.8\%; commuting, $26.0 \%$; shopping, $24.8 \%$; business, $23.5 \%$; and others, $1.3 \%$ (see in Table 1 ).

This result may suggest that the Java respondents tend to use car sharing services as a temporary mode for traveling, rather than considering it as the main mode for a full commute or a feeder mode. This is also in line with the result from the semi-structured interview with young Indonesian students that are more likely to use car sharing services for traveling or visiting their parents and friends.

\subsection{Use Intention of Car Sharing}

This section summarizes the responses to the questions (statements) that seek to understand the respondents' intentions or willingness to use car sharing. Table 2 shows the responses; $77.3 \%$ of Java respondents stated that they would like to use car sharing services if the service is available in their towns. Nearly $80 \%$ of the respondents opined that they would use car sharing more, especially during the rainy season, if no car is available in their houses. This can be understood in the same context of the findings from the previous interviews, which is that climatic attributes might influence an individual's travel decision for the Southeast-Asia region. Furthermore, 77.4\% support the idea that car sharing systems meet the mobility demand of people. 
Table 2. Responses to the statements related to car sharing usage (\% respondents in each statement).

\begin{tabular}{|c|c|c|c|c|c|c|c|c|c|}
\hline Statements & 1 Strongly Disagree & 2 & 3 & 4 Neutral & 5 & 6 & 7 Strongly Agree & Mean & SD \\
\hline \multicolumn{10}{|c|}{ Respondents' intentions to use car sharing } \\
\hline $\begin{array}{l}\text { S1. I would like to use car-sharing services if the service } \\
\text { is available in my town }\end{array}$ & 4.5 & 1.8 & 4.3 & 12.0 & 19.8 & 24.7 & 32.8 & 5.46 & 1.59 \\
\hline $\begin{array}{l}\text { S2. If no car is available in my household, I would like to } \\
\text { use car sharing more especially during the rainy season }\end{array}$ & 3.0 & 3.0 & 4.5 & 10.5 & 24.0 & 26.0 & 29.0 & 5.44 & 1.51 \\
\hline $\begin{array}{l}\text { S3. I support car sharing systems to meet the mobility } \\
\text { demand of people }\end{array}$ & 2.0 & 2.8 & 5.8 & 11.8 & 24.3 & 27.8 & 25.3 & 5.39 & 1.44 \\
\hline \multicolumn{10}{|c|}{ Respondents' perceptions toward car sharing usage and related aspects of car ownership } \\
\hline $\begin{array}{l}\text { S4. Owing a car rather than using car sharing is a better } \\
\text { way to change my social image }\end{array}$ & 5.7 & 7.2 & 11.3 & 21.8 & 21.0 & 19.8 & 13.2 & 4.58 & 1.67 \\
\hline $\begin{array}{l}\text { S5. People who possess their own cars look richer than } \\
\text { people who do not possess their own cars }\end{array}$ & 13.5 & 8.2 & 13.0 & 17.2 & 20.5 & 17.0 & 10.7 & 4.17 & 1.87 \\
\hline $\begin{array}{l}\text { S6. It is a shame if my family use car sharing instead of } \\
\text { owning a car to use }\end{array}$ & 33.2 & 17.8 & 10.7 & 12.5 & 10.8 & 9.3 & 5.7 & 3.01 & 1.95 \\
\hline $\begin{array}{l}\text { S7. Owning a private car suffers from the risk in terms of } \\
\text { maintenance, repair and accident management }\end{array}$ & 2.5 & 4.7 & 5.2 & 15.3 & 23.5 & 25.3 & 23.5 & 5.23 & 1.53 \\
\hline S8. Using car sharing makes me feel comfortable & 2.5 & 3.3 & 8.3 & 24.7 & 22.7 & 23.2 & 15.3 & 4.92 & 1.46 \\
\hline $\begin{array}{l}\text { S9. Car sharing helps me to use a more convenient and } \\
\text { safe mode of transport }\end{array}$ & 1.3 & 2.0 & 4.7 & 20.2 & 20.5 & 28.7 & 22.7 & 5.33 & 1.37 \\
\hline $\begin{array}{l}\text { S10. Using car sharing is a reasonable choice for a person } \\
\text { who does not own his/her car }\end{array}$ & 1.3 & 2.2 & 4.5 & 12.3 & 18.8 & 31.5 & 29.3 & 5.57 & 1.37 \\
\hline S11. Using car sharing makes me save money & 2.2 & 4.0 & 7.5 & 22.0 & 20.8 & 24.5 & 19.0 & 5.05 & 1.49 \\
\hline $\begin{array}{l}\text { S12. I believe that car sharing can lead to substantial cost } \\
\text { savings compared to a private car }\end{array}$ & 2.2 & 3.0 & 7.0 & 19.0 & 23.3 & 26.8 & 18.7 & 5.14 & 1.45 \\
\hline
\end{tabular}




\subsection{Respondents' Perceptions toward Car Sharing Usage}

The attitudinal questions (statements) were asked to understand the respondents' perceptions toward car sharing usage. The statements were made to capture their perception of car ownership related to social status, risks and burdens, their perceived benefits of car sharing related to convenience, and cost-saving aspects. The descriptive statistics corresponding to those statements are summarized in Table 2.

Of the respondents, $54 \%$ agreed that car ownership is a better way of changing their social image rather than using car sharing. Just above $48 \%$ of respondents agreed that people who possess their own cars look richer than people who do not so. Respondents agreed less (about 25.8\%) with the statement that it is a shame if their family use car sharing instead of owning a car to use, possibly because of a negative undertone perceived with the word "shame."

About $72 \%$ of respondents agreed that owning a private car suffers from risk in terms of maintenance, repair, and accident management. Positive response to this statement is consistent with the findings from the previous interviews. Further disaggregation of the responses shows interesting results. Car owners have more positive responses to the statement representing the burdens of car ownership, which means that they perceive car ownership as burdensome and risky. Non-owners appear to disagree with the perceived image of car ownership as burdensome and risky (mean $=2.41$, $\mathrm{SD}=1.53$ ), though the small sample size leads to a bias.

As to the statements that were designed to capture the respondents' perceived benefits of car sharing related to comfort and convenience, $61.2 \%$ of respondents had the idea that using car sharing makes them feel comfortable. Approximately $72 \%$ agreed that car sharing helps them to use a more convenient and safe mode of transport.

When summarized, the responses to the attitudinal statements regarding the perceived benefits of car sharing related to cost aspects; about $80 \%$ of the respondents agreed that using car sharing is a reasonable choice for a person who does not own a car. Nearly $64 \%$ agreed with the statement that using car sharing makes them save money. Similarly, approximately $69 \%$ believed that car sharing could lead to substantial cost savings compared to a private car.

\section{Empirical Analysis Based on the Ordered Logit Models}

This study investigated whether and how potential factors (independent variables) affect behavioral intentions (dependent variable) of the Java residents to adopt and use car sharing by employing ordered logit models.

\subsection{Dependent Variables: Car Sharing Use Intention}

The survey contained three questions asking respondents' intention to use car sharing: "I would like to use car sharing services if the service is available in my town (S1)", "If no car is available in my household, I would like to use car sharing more especially during the rainy season (S2)", and "I support car sharing systems to meet the mobility demand of people (S3)." These were to understand the respondents' car sharing use intention, which was defined in this study as agreement or assessment of future willingness to use, and their support for the idea of car sharing. Responses to all of these statements formed the dependent variables, $\operatorname{CSI}_{l i}(l$ : item index, $i$ : respondent index) and three ordered logit models were estimated, one for each statement (item) separately representing the intention of using car sharing.

\subsection{Independent Variables: Potential Factors Related to Car Sharing Usage}

Each statement (item) from S4 to S12 in Table 2 can be linked to or constructed in the potential factor. For instance, one can conceive that the first three items (S4-S6) in Table 2 relate to perceived psychosocial values of car ownership as societal status. Another example is the fourth item (S7) in Table 2 that focuses on perceived risks and burdens of car ownership. As such, the 9 items (S4-S12) in Table 2 could 
cover three constructs, indicating each potential factor: (i) Perceived values of car ownership as societal status, PS (S4-S6); (ii) perceived risks and burdens of car ownership, $P R$ (S7); and (iii) perceived benefits of car sharing related to convenience and cost-saving aspects, $P B$ (S8-S12). This study examined the reliability and consistency of the scales using exploratory factor analysis and Cronbach's alpha coefficients [73] (see Table A5 in Appendix F). The three and five items for each construct (PS and $P B$, respectively) loaded together on a single factor, and none of the cross-loadings exceeded 0.40 . The scales exhibited acceptable reliability, although the reliability of the perceived psychosocial values of car ownership as societal status-scale (0.643) was slightly below the recommended level.

Three separate ordered logit models estimated the effects of $P R, P S$, and $P B$ on the 7-point score for each item of car sharing use intention $\left(C S I_{l}\right)$. In the analyses, the variables, $P S$, and $P B$ take values from 1 to 7 (1: Strongly disagree to 7: Strongly agree), respectively. $P R$ takes the value 1 if the respondent is strongly agreed that car ownership suffers from risks and burdens of maintenance, repair, and accident management, else 0 .

\subsection{Estimation Results}

Table 3 presents the estimation results of the ordered logit models relating the car sharing use intention (CSI) to the extracted factors (e.g., $P S, P R$, and $P B$ ) and income attribute. The three ordered logit models in Table 3 suggest that the perceived benefits of car sharing related to convenience and cost-saving aspects $(P B)$ have a significant positive $(p<0.01)$ main effect on $C S I$, supporting hypothesis H1. Results also show that those who support the idea that car sharing systems that meet the mobility demand of people are the most likely to perceive that car sharing brings them convenience and monetary advantages. Perceived values of car ownership related to societal status (PS) had a negative effect on CSI at a significance level of $5 \%$ or $10 \%$. These results support hypothesis H3. The estimated results show that perceived risks and burdens of car ownership $(P R)$ are significant in some but not all the models. The natural logarithm of income had a positive effect for CSI, highly significant in the model $(p<0.01)$ where people were more likely to use car sharing especially during the rainy season, and nearly significant $(p<0.1)$ in the other two models-Items 1 and 3.

Table 3. Results by ordered logit models: intention of car sharing use.

\begin{tabular}{cccc}
\hline \multirow{2}{*}{ Variables } & \multicolumn{3}{c}{ Car Sharing Use Intention $\left(\mathrm{CSI}_{l i}\right)$} \\
\cline { 2 - 4 } & Item 1 (S1) Value & Item 2 (S2) Value & Item 3 (S3) Value \\
\hline Income & $0.208^{*}$ & $0.309^{* * *}$ & $0.230^{*}$ \\
Composite index & & & \\
$P B$ & $1.435^{* * *}$ & $1.398^{* * *}$ & $1.754^{* * *}$ \\
$P S$ & $-0.134^{* *}$ & $-0.138^{* *}$ & $-0.098^{*}$ \\
$P R$ & $0.084^{* * *}$ & $0.575^{* * *}$ & $0.381^{*}$ \\
\hline Threshold 1 & $3.567^{* * *}$ & $3.323^{* * *}$ & $3.722^{* * *}$ \\
Threshold 2 & $4.054^{* * *}$ & $4.296^{* * *}$ & $5.139^{* * *}$ \\
Threshold 3 & $4.839^{* * *}$ & $5.130^{* * *}$ & $6.422^{* * *}$ \\
Threshold 4 & $6.112^{* * *}$ & $6.253^{* * *}$ & $7.832^{* * *}$ \\
Threshold 5 & $7.483^{* * *}$ & $7.902^{* * *}$ & $9.725^{* * *}$ \\
Threshold 6 & $8.967^{* * *}$ & $9.554^{* * *}$ & $11.704^{* * *}$ \\
\hline Sample size & $600^{* * *}$ & 600 & 600 \\
Pseudo R & $0.176^{2}$ & 0.180 & $0.239^{*}$ \\
\hline
\end{tabular}

$* p<0 . \overline{1, * *} p<0.05,{ }^{* * *} p<0.01$. Abbreviations: $P S$, perceived values of car ownership related to societal status; $P R$, perceived risks and burdens of car ownership; $P B$, perceived benefits of car sharing related to convenience and cost-saving aspects.

The factor changes in the odds for a unit increase in independent variables is derived by exponentiating the ordered logit coefficients. For instance, the ordered logit coefficient value of $P B$ to CSI in the Item 1 model, $\hat{\tau}_{1}$ is 1.435 and $\exp \left(\hat{\tau}_{1}\right)=4.20$. The odds of the outcome 'agree (somewhat 
agree)' toward car sharing use intention are 4.20 times greater than the outcome 'somewhat agree (neutral)' for a one-unit change in $P B$. In other words, if the level of people's perceived benefits of car sharing is increased by a one-unit, (provided that the service is available in town) their intention or willingness to use car sharing is likely to increase by 4.2 times ( $320 \%)$.

\subsection{Planning, Business Opportunities, and Policy Implications}

Our ordered logit models show that individuals' intentions to use car sharing can be strongly influenced by the perceived benefits of car sharing related to convenience aspects and monetary advantages. Business providers might offer users a reasonable and transparent pricing system, allowing users to easily understand the cost-saving benefits of car sharing compared to expenses of private car ownership. In addition, car sharing schemes should focus on convenience aspects that help users feel their life more comfortable and safer through car sharing usage.

From a broad perspective, those who have a higher psychosocial valuation of car ownership in terms of social image or status symbol are less likely to join car sharing schemes. When people's perceived values of cars related to societal status remain high or even rise, this will become a rather strong motivation for purchasing and owning a car [59]. Thus, future planning strategies may include effective measures to decrease the psychosocial values of car ownership, if they aim at the proliferation of car sharing schemes and curbing private car ownership.

The findings do not corroborate our prediction that risks and responsibilities, accompanied by owning a product, are important reasons for users to decide for car sharing use. It should be noted, however, that most respondents owned their cars. This, in turn, suggests that any strategy highlighting that a service provider takes responsibilities (e.g., maintenance, repair, etc.) may not strongly appeal to prospective users, at least those who own their cars.

Interestingly, results reveal that income has a positive effect on car sharing use intention in Java, Indonesia. This suggests that as individuals' income levels become higher, they are more likely to consider car sharing use. Moreover, people with higher income are more likely to use car sharing during the rainy season. Further analysis shows that income and car ownership (no car in his/her household $=0$, otherwise: More than one car in household $=1$ ) are positively correlated at a significance level of $1 \%$. Looking at this, we might surmise that Java residents in the high-income level bracket who own their cars aspire to experience a new mobility option or a wide variety of vehicles through car sharing usage.

\subsection{Limitations}

This survey obviously focuses on individuals who are internet users, possibly slighting other residents who are not computer users. Considering that $32 \%$ of the population in Indonesia used the internet [74], the focus of the online survey tended to bias towards the bracket who were more likely to own an internet environment or to easily get access to the internet. However, most car sharing services currently need to be reserved by access to the internet. The survey result, hence, may represent the voice of the prospective users who are capable of booking and using (accessible to) the services at least.

Another is that the survey was focused heavily on individuals who own a car in their households, thus overrepresenting Indonesian's car ownership levels. Thus, the generalization is limited, and this issue requires further investigation to include exploring non-car owners' perceptions and intentions of car sharing use. Nonetheless, the results obtained from distinct groups of customers who share specific characteristics can be used in tailored marketing strategies to appeal to the distinct target markets.

While the semi-structured interviews used in this study allowed us to develop a much deeper understanding of the research question, the interview design was targeted only at the analysis of university students aged between 20 and 25 . In addition, the random sample of residents in Java Island among all age groups was predominantly limited in the age group of 20-39. Although younger people are the most likely target audience for car sharing services [6], not accounting for other age groups could lead to underestimating uncertainty in their intentions and willingness. 


\section{Conclusions}

This paper attempts to provide a comprehensive understanding of factors influencing the future car sharing decision of individuals in the Southeast-Asia region, like Indonesia. The semi-structured interviews were conducted to specify the perception of car sharing usage and related aspects of car ownership. This allows us to probe into several potential factors affecting the decision on car sharing usage in the Southeast-Asia region. Main findings of the semi-structured interviews include:

i. University students in Thailand and Indonesia, in response to the current transportation mode, appear to be satisfied with using motorcycles in their daily lives due to its affordability.

ii. They are interested in car sharing usage, but more likely to choose classic styles of car sharing (station-based one- or two-way services).

iii. Students in Indonesia are concerned about the burden of car ownership in terms of repair, maintenance, replacement, and accident management.

iv. Students in Thailand show willingness to buy or use a car, especially during the rainy season.

v. Convenience aspects are of importance as the main criteria for choosing to use car sharing services.

Based on the above findings, the online survey gathered 600 individuals' perception about the benefits of car sharing and car ownership related to status, burdens, risks, etc., apart from the usual set of personal and household socio-demographic profiles. Descriptive analysis followed, by three ordered logit models, were employed for exploring the car sharing use intention of respondents in Java, Indonesia. The important findings of the descriptive and econometric analysis include:

i. Nearly $70 \%$ of respondents are more likely to choose classic types of car sharing, corroborating the findings from the semi-structured interviews.

ii. Respondents mostly want to use car sharing services for traveling the most, followed by commuting, and shopping.

iii. Individuals who agree that car sharing brings us convenience and cost-saving benefits are more likely to use car sharing services.

iv. Individuals who opine that cars allow to express one's social image and societal status are less likely to use car sharing services.

v. Respondents in a higher income-level bracket are more likely to use car sharing services.

The overall conclusion is that there is a demand for car sharing use in the Southeast-Asia region, like Indonesia. The factors addressed in this study will help a transportation planner or business practitioner to better understand characteristics, as well as to devise efficient car sharing schemes for large cities or areas in Southeast-Asian developing countries.

Author Contributions: Conceptualization, Y.-Y.C., M.M., and K.T.; formal analysis, Y.-Y.C., K.C., and H.E.; supervision, M.M. and K.T.; validation, K.C. and H.E.; writing-original draft, Y.-Y.C.; writing一review and editing, Y.-Y.C., M.M., K.T., K.C., and H.E.

Funding: This research was supported by the Environment Research and Technology Development Fund (S16) of the Environmental Restoration and Conservation Agency of Japan.

Acknowledgments: The authors would like to thank Viganda Varabuntoonvit (Kasetsart University, Bangkok) and Yun Arifatul Fatimah (Muhammadiyah University, Magelang) for their help with the arrangement and discussion during the semi-structured interviews in Thailand and Indonesia, respectively.

Conflicts of Interest: The authors declare no conflicts of interest. 


\section{Appendix A. Summary of the Literature Review Analysis}

Table A1. The literature review analysis of the case studies considered in this study.

\begin{tabular}{|c|c|c|c|c|}
\hline No. & Authors & Studied Area & Investigated Area & Focus of the Study \\
\hline 1 & Cullinane (2002) & Hong Kong, China & University students & Relationship between car ownership and public transport provision \\
\hline 2 & Fukuda et al. (2005) & Bangkok, Thailand & $\begin{array}{l}\text { Employers and/or residences near } \\
\text { stations }\end{array}$ & Potential market characteristics of station-based ${ }^{1}$ car sharing \\
\hline 3 & Burkhardt and Millard-Ball (2006) & North America & Car sharing members & $\begin{array}{l}\text { Demographic markets examining demographic, travel, and attitudinal } \\
\text { characteristics of current car sharing members, including motivating } \\
\text { factors for (round-trip) car sharing }\end{array}$ \\
\hline 4 & Cervero et al. (2007) & San Francisco Bay Area, United States & $\begin{array}{c}\text { Car sharing members and } \\
\text { non-members }\end{array}$ & $\begin{array}{l}\text { Travel characteristics, including demographics, and car ownership } \\
\text { attributes of current car sharing members and non-members, and } \\
\text { long-term impacts of (round-trip) car sharing }\end{array}$ \\
\hline 5 & Hampshire and Gaites (2011) & Pittsburgh, Pennsylvania, United States & Car owners & $\begin{array}{l}\text { Success factors for car sharing and market feasibility of } \\
\text { peer-to-peer carsharing }\end{array}$ \\
\hline 6 & Costain et al. (2012) & Toronto, Canada & Car sharing members & $\begin{array}{l}\text { Key travel characteristics of current car sharing members and car sharing } \\
\text { users' attitudes toward environment and safety (round-trip car sharing) }\end{array}$ \\
\hline 7 & Zhu et al. (2012) & Shanghai, Zhenjiang, China & College students & $\begin{array}{l}\text { Desire for car ownership and whether the desire is influenced by its } \\
\text { psychosocial or its instrumental value }\end{array}$ \\
\hline 8 & Efthymiou et al. (2013) & Greece & The age group of $18-35$ years old & $\begin{array}{l}\text { Potential market characteristics of station-based }{ }^{1} \text { car sharing use, } \\
\text { current travel patterns and perception toward car sharing, and the } \\
\text { factors affecting the adoption of car sharing }\end{array}$ \\
\hline 9 & Schaefers (2013) & United States & Car sharing customers & $\begin{array}{l}\text { Exploration of car sharing usage motives (free-floating car sharing) by } \\
\text { considering non-observable factors influencing consumer behavior }\end{array}$ \\
\hline 10 & Ballús-Armet et al. (2014) & San Francisco Bay Area, United States & Individuals (residents) & $\begin{array}{c}\text { Public perception of peer-to-peer car sharing and its potential } \\
\text { market characteristics }\end{array}$ \\
\hline 11 & Coll et al. (2014) & Québec, Canada & Car sharing members & $\begin{array}{c}\text { Geographical and socio-economic factors that favor membership of } \\
\text { station-based }{ }^{1} \text { car sharing }\end{array}$ \\
\hline 12 & Lindloff et al. (2014) & Germany & Car sharing users & Qualitative analysis of car sharing usage motives (round-trip car sharing) \\
\hline 13 & De Luca and Di Pace (2015) & Salerno metropolitan area, Italy & Individuals (residents) & $\begin{array}{l}\text { Acceptability of an inter-urban one-way car sharing program, and its } \\
\text { effects on mode choice behavior }\end{array}$ \\
\hline 14 & Kim (2015) & New York City, United States & Car sharing members & $\begin{array}{l}\text { Whether station-based }{ }^{1} \text { car sharing can help meet the mobility demand } \\
\text { for urban residents in the marginalized neighborhoods; association of a } \\
\text { neighborhood's socio-demographic characteristics with station-based }{ }^{1} \\
\text { car sharing usage by investigating shared vehicle utilization pattern }\end{array}$ \\
\hline 15 & Verma (2015) & India & Individuals (residents) & Reasons and factors affecting car ownership \\
\hline
\end{tabular}


Table A1. Cont.

\begin{tabular}{ccccc}
\hline No. & Authors & Studied Area & Investigated Area & Focus of the Study \\
\hline 16 & Verma et al. (2016) & Bangalore, India & University students & $\begin{array}{c}\text { Young adults' perception of car travel, their attitudes towards the travel } \\
\text { environment, and factors influencing the future car ownership decision }\end{array}$ \\
\hline 17 & Belgiawan et al. (2016) & Bandung, Indonesia & University students & $\begin{array}{c}\text { Motivation and factors determining car ownership decision among } \\
\text { young people }\end{array}$ \\
\hline 18 & Clewlow (2016) & San Francisco Bay Area, United States & $\begin{array}{c}\text { Car sharing members and } \\
\text { non-members (comparison) }\end{array}$ & $\begin{array}{c}\text { Comparison of the demographics and travel behavior of carshare } \\
\text { members versus non-members, utilizing data from the travel survey }\end{array}$ \\
\hline 19 & Schaefers et al. (2016) & United States & Car sharing customers & $\begin{array}{c}\text { Effects of financial, performance, and social risks on the intensity of } \\
\text { access-based service usage and an access-based service's influence on } \\
\text { ownership reduction using a car sharing case }\end{array}$ \\
\hline 20 & Prieto et al. (2017) & $\begin{array}{c}\text { London (UK), Madrid (Spain), Paris } \\
\text { (France), Tokyo (Japan) }\end{array}$ & $\begin{array}{c}\text { Car owners in four major } \\
\text { metropolitan areas }\end{array}$ & $\begin{array}{c}\text { Effects of socio-demographic variables on car sharing behavior and } \\
\text { individual choice between station-based }{ }^{1} \text { and peer-to-peer car } \\
\text { sharing systems }\end{array}$ \\
\hline & 1 Station-based car sharing systems: Two-way (round-trip) or one-way car sharing systems, where available cars are parked in dedicated parking stations for the services.
\end{tabular}




\section{Appendix B. Semi-Structured Interview Questions}

- How do you commute to your school? Usually, what types of transport mode do you use for your day trips? Are you satisfied with your current mode? How about the current public transportation system?

- Are you a car owner? Are you willing to buy a car in the future? How do you think of the advantages and disadvantages of car ownership?

- Would you likely to choose to use car sharing services? What types of car sharing services would you likely to use? When do you likely to use car sharing services the most?

- What kind of factors might affect you to choose car sharing services?

\section{Appendix C. Questionnaire Design}

Table A2. Statements towards the perception of car sharing and other aspects related to car ownership for car sharing usage.

\begin{tabular}{cc}
\hline \multicolumn{1}{c}{ Statements } & Source \\
\hline $\begin{array}{c}\text { S4. Owing a car rather than using car sharing is a } \\
\text { better way to change my social image }\end{array}$ & Adapted from Verma et al. (2016) \\
\hline $\begin{array}{c}\text { S5. People who possess their own cars look richer } \\
\text { than people who do not possess their own cars }\end{array}$ & $\begin{array}{c}\text { Motivated by the interview results and adapted from } \\
\text { Verma et al. (2016) }\end{array}$ \\
\hline $\begin{array}{c}\text { S6. It is a shame if my family use car sharing instead } \\
\text { of owning a car to use }\end{array}$ & $\begin{array}{c}\text { Adapted from Verma et al. (2016) and Belgiawan et al. } \\
\text { (2016) }\end{array}$ \\
\hline $\begin{array}{c}\text { S7. Owning a private car suffers from the risk in terms } \\
\text { of maintenance, repair and accident management }\end{array}$ & Adapted from Schaefers et al. (2016) \\
\hline S8. Using car sharing makes me feel comfortable & Motivated by the interview results \\
\hline $\begin{array}{c}\text { S9. Car sharing helps me to use a more convenient } \\
\text { and safe mode of transport }\end{array}$ & Motivated by the interview results and adapted from \\
Fukuda et al. (2005)
\end{tabular}

Appendix D. Detailed Information about Demographic Profile of the Online Survey Respondents

Table A3. Demographic profile of the respondents.

\begin{tabular}{cc}
\hline Category & No. of Respondents ${ }^{\mathbf{1}}$ \\
\hline Gender & $300(50.0)$ \\
Male & $300(50.0)$ \\
Female & \\
Age & $1(0.2)$ \\
$<20$ & $268(44.7)$ \\
$20-29$ & $218(36.3)$ \\
$30-39$ & $100(16.7)$ \\
$40-49$ & $12(2.0)$ \\
$50-59$ & $1(0.2)$ \\
$60-69$ & $0(0.0)$ \\
$>70$ &
\end{tabular}


Table A3. Cont.

\begin{tabular}{|c|c|}
\hline Category & No. of Respondents ${ }^{1}$ \\
\hline \multicolumn{2}{|l|}{ Household annual income (M-IDR $\left.{ }^{2}\right)$} \\
\hline$<30$ & $96(16.0)$ \\
\hline $30-59$ & $108(18.0)$ \\
\hline $60-89$ & $110(18.3)$ \\
\hline $90-114$ & $75(12.5)$ \\
\hline 115-119 & $43(7.2)$ \\
\hline $120-134$ & $58(9.7)$ \\
\hline 135-149 & $46(7.7)$ \\
\hline$>150$ & $64(10.7)$ \\
\hline \multicolumn{2}{|l|}{ Household type } \\
\hline Single & $156(26.0)$ \\
\hline Couple without children & $52(8.7)$ \\
\hline $\begin{array}{c}\text { An adult with one or several } \\
\text { children }\end{array}$ & $84(14.0)$ \\
\hline $\begin{array}{c}\text { Couple with one or several } \\
\text { children }\end{array}$ & $304(50.7)$ \\
\hline Other & $4(0.7)$ \\
\hline \multicolumn{2}{|l|}{ Localization } \\
\hline Metropolitan area center & $231(38.5)$ \\
\hline Local city area & $258(43.0)$ \\
\hline Metropolitan area suburb & $78(13.0)$ \\
\hline Rural area & $31(5.2)$ \\
\hline Other & $2(0.3)$ \\
\hline \multicolumn{2}{|l|}{ Employment status } \\
\hline Employed & $528(88.0)$ \\
\hline Unemployed & $6(1.0)$ \\
\hline Student & $30(5.0)$ \\
\hline Retired & $0(0.0)$ \\
\hline Other & $36(6.0)$ \\
\hline \multicolumn{2}{|l|}{ Educational level } \\
\hline Completed some high school & $7(1.2)$ \\
\hline High school graduated & $148(24.7)$ \\
\hline College or university degree & $418(69.7)$ \\
\hline Postgraduate degree & $27(4.5)$ \\
\hline \multicolumn{2}{|l|}{ Car ownership (per household) } \\
\hline One car & $466(77.7)$ \\
\hline Two cars & $96(16.0)$ \\
\hline Three cars or more & $16(2.7)$ \\
\hline No car & $22(3.7)$ \\
\hline \multicolumn{2}{|l|}{ Vehicle driving frequency-car } \\
\hline All days (including weekends) & $165(27.5)$ \\
\hline All days (midweek) & $88(14.7)$ \\
\hline Once to three times a week & $225(37.5)$ \\
\hline Once to three times a month & $52(8.7)$ \\
\hline Less than once a month & $31(5.2)$ \\
\hline I do not have a driver's license & $39(6.5)$ \\
\hline \multicolumn{2}{|l|}{ Vehicle driving frequency-motorcycle } \\
\hline All days (including weekends) & $283(47.2)$ \\
\hline All days (midweek) & $180(30.0)$ \\
\hline Once to three times a week & $80(13.3)$ \\
\hline Once to three times a month & $25(4.2)$ \\
\hline Less than once a month & $15(2.5)$ \\
\hline I do not have a driver's license & $17(2.8)$ \\
\hline Overall sample & $600(100.0)$ \\
\hline
\end{tabular}

${ }^{1}$ Values in parentheses are the percentages of sample respondents. ${ }^{2}$ M-IDR: Million Indonesian Rupiahs. 
Table A4. Demographic profile of the respondents—by gender per age group.

\begin{tabular}{cc}
\hline Category & No. of Respondents ${ }^{1}$ \\
\hline Male, $<20$ & $1(0.2)$ \\
Male, 20-29 & $117(19.5)$ \\
Male, 30-39 & $108(18.0)$ \\
Male, $40-49$ & $66(11.0)$ \\
Male, 50-59 & $7(1.2)$ \\
Male, 60-69 & $1(0.2)$ \\
Male, $>70$ & $0(0.0)$ \\
\hline Female, $<20$ & $0(0.0)$ \\
Female, 20-29 & $151(25.2)$ \\
Female, 30-39 & $110(18.3)$ \\
Female, 40-49 & $34(5.7)$ \\
Female, 50-59 & $5(0.8)$ \\
Female, 60-69 & $0(0.0)$ \\
Female, $>70$ & $0(0.0)$ \\
\hline Values in parentheses are the percentage of sample respondents.
\end{tabular}

\section{Appendix E. Additional Information Provided for the Online Survey Questionnaire}

Car sharing is a model where users can rent cars on an hourly or daily basis.

- Two-way car sharing is a traditional model where a customer must start and finish his/her journey in the same place.

- One-way car sharing is similar to the two-way one, but a customer can return the vehicle to a location of choice, which means that there is no need to finish the journey in the same place.

- A free-floating car sharing user can freely park it in any legal parking space, while a customer that uses a two-way or one-way car-sharing needs to park the used vehicle in the designated stations.

- $\quad \mathrm{P} 2 \mathrm{P}$ car sharing is a type to vehicle sharing in which vehicle owners temporarily rent their personal cars to others, and is not centrally-managed.

Please note that car sharing is different from ride-sharing or ride hailing. The key distinction of car sharing is that the shared car is driven by the end user, not a paid chauffeur.

\section{Appendix F. Factor Analysis Results}

Table A5. Item descriptions and factor analysis results ${ }^{1}$.

\begin{tabular}{rcc}
\hline & Stem and Items & Factor Loadings \\
\hline Perceived values of car ownership as societal status $(\alpha=0.643)$ & \\
\hline (S5) People who possess their own cars look richer than people who do not possess their own cars & $\mathbf{0 . 8 1 5}$ & 0.080 \\
\hline (S6) It is a shame if my family use car sharing instead of owning a car to use & $\mathbf{0 . 7 5 8}$ & -0.056 \\
\hline (S4) Owing a car rather than using car sharing is a better way to change my social image & $\mathbf{0 . 7 0 7}$ & 0.150 \\
\hline Perceived benefits of car sharing related to convenience and cost-saving aspects ( $\alpha=0.870)$ & \\
\hline (S9) Car sharing helps me to use a more convenient and safe mode of transport & -0.011 & $\mathbf{0 . 8 4 8}$ \\
\hline (S12) I believe that car sharing can lead to substantial cost savings compared to a private car & 0.042 & $\mathbf{0 . 8 3 2}$ \\
\hline (S8) Using car sharing makes me feel comfortable & 0.203 & $\mathbf{0 . 7 9 8}$ \\
\hline (S11) Using car sharing makes me save money & 0.120 & $\mathbf{0 . 7 9 2}$ \\
\hline (S10) Using car sharing is a reasonable choice for a person who does not own his/her car & -0.022 & $\mathbf{0 . 7 7 1}$ \\
\hline
\end{tabular}

\footnotetext{
${ }^{1}$ Loadings greater than $|0.40|$ are bolded for visual clarity.
} 


\section{References}

1. Belgiawan, P.F.; Schmöcker, J.D.; Fujii, S. Understanding car ownership motivations among Indonesian students. Int. J. Sustain. Transp. 2016, 10, 295-307. [CrossRef]

2. Yamakawa, H. ASEAN New Car Sales Reach 3.33 Million in 2017-Two-Thirds the Scale of the Japanese market. In IIST e-Magazine; FY2018 (No.0279-1077); Institute for International Studies and Training: Tokyo, Japan, 2018. Available online: https://www.cfiec.jp/en-m/2018/0279-1077/ (accessed on 25 August 2019).

3. Dargay, J.; Gately, D.; Sommer, M. Vehicle ownership and income growth, worldwide: 1960-2030. Energy J. 2007, 28, 143-170. [CrossRef]

4. Nugroho, S.B.; Zusman, E.; Nakano, R.; Takahashi, K.; Kaswanto, R.L.; Arifin, H.S.; Arifin, N.; Munandar, A.; Muchtar, M.; Gomi, K.; et al. Exploring influential factors on transition process of vehicle ownership in developing Asian city, A case study in Bogor city Indonesia. In Proceedings of the 2017 IEEE 20th International Conference on Intelligent Transportation Systems (ITSC), Yokohama, Japan, 16-19 October 2017; IEEE: Piscataway, NJ, USA, 2018; pp. 674-679.

5. Shen, Q.; Chen, P.; Pan, H. Factors affecting car ownership and mode choice in rail transit-supported suburbs of a large Chinese city. Transp. Res. Part A 2016, 94, 31-44. [CrossRef]

6. Efthymiou, D.; Antoniou, C.; Waddell, P. Factors affecting the adoption of vehicle sharing systems by young drivers. Transp. Policy 2013, 29, 64-73. [CrossRef]

7. Martin, E.; Shaheen, S.; Lidicker, J. Impact of carsharing on household vehicle holdings: Results from North American shared-use vehicle survey. Transp. Res. Rec. 2010, 2143, 150-158. [CrossRef]

8. Millard-Ball, A.; Murray, G.; ter Schure, J. Car-Sharing as a Parking Management Strategy. In Proceedings of the 85th Annual Meeting of the Transportation Research Board, Washington, DC, USA, 1-2 November 2006.

9. Ferrero, F.; Perboli, G.; Rosano, M.; Vesco, A. Car-sharing services: An annotated review. Sustain. Cities Soc. 2018, 37, 501-518. [CrossRef]

10. Cervero, R.; Golub, A.; Nee, B. City CarShare: Longer-term travel demand and car ownership impacts. Transp. Res. Rec. 2007, 1992, 70-80. [CrossRef]

11. Firnkorn, J.; Müller, M. What will be the environmental effects of new free-floating car-sharing systems? The case of car2go in Ulm. Ecol. Econ. 2011, 70, 1519-1528. [CrossRef]

12. Shaheen, S.A.; Cohen, A.P. Growth in worldwide carsharing: An international comparison. Transp. Res. Rec. 2007, 1992, 81-89. [CrossRef]

13. Kim, K. Can carsharing meet the mobility needs for the low-income neighborhoods? Lessons from carsharing usage patterns in New York City. Transport. Res. Part A 2015, 77, 249-260. [CrossRef]

14. Rodier, C. Review of International Modeling Literature: Transit, land use, and auto pricing strategies to reduce vehicle miles traveled and greenhouse gas emissions. Transp. Res. Rec. 2009, 2132, 1-12. [CrossRef]

15. Shaheen, S.A.; Lipman, T.E. Reducing greenhouse emissions and fuel consumption: Sustainable approaches for surface transportation. IATSS Res. 2007, 31, 6-20. [CrossRef]

16. Shaheen, S.; Rodier, C. Travel effects of a suburban commuter carsharing service: CarLink case study. Transp. Res. Rec. 2005, 1927, 182-188. [CrossRef]

17. Shaheen, S.; Schwartz, A.; Wipyewski, K. Policy considerations for carsharing and station cars: Monitoring growth, trends, and overall impacts. Transp. Res. Rec. 2004, 1887, 128-136. [CrossRef]

18. Briggs, M. Future of Mobility: Future \& Visions of Collaborative Mobility. In Proceedings of the Frost and Sullivan Intelligent Mobility—Future Business Models in Connected and Automated Mobility, London, UK, 1-2 July 2015. Available online: https:/www.wocomoco.org/assets/docs/Infomaterialien-Kongress-2015/ Praesentationen/BriggsWocomoco_FrostSullivan_26062015.pdf (accessed on 1 August 2018).

19. Le Vine, S.; Zolfaghari, A.; Polak, J. Carsharing: Evolution, challenges and opportunities. In Proceedings of the 22nd European Automobile Manufacturers Association (ACEA) Scientific Advisory Group Report, Brussel, Belgium, 22 September 2014; pp. 1-20.

20. De Luca, S.; Di Pace, R. Modelling users' behaviour in inter-urban carsharing program: A stated preference approach. Transport. Res. Part A 2015, 71, 59-76. [CrossRef]

21. Lindloff, K.; Pieper, N.; Bandelow, N.C.; Woisetschläger, D.M. Drivers of carsharing diffusion in Germany: An actor-centred approach. Int. J. Automot. Technol. Manag. 2014, 14, 217-245. [CrossRef]

22. Wagner, C.; Shaheen, S. Car sharing and mobility management: Facing new challenges with technology and innovative business planning. World Transp. Policy Pract. 1998, 4, 39-43. 
23. Agatz, N.; Erera, A.; Savelsbergh, M.; Wang, X. Optimization for dynamic ride-sharing: A review. Eur. J. Oper. Res. 2012, 223, 295-303. [CrossRef]

24. Clewlow, R.R.; Mishra, G.S. Disruptive Transportation: The Adoption, Utilization, and Impacts of Ride-Hailing in the United States; Institute of Transportation Studies Research Report UCD-ITS-RR-17-07; University of California: Davis, CA, USA, 2017.

25. De Almeida Correia, G.H.; Antunes, A.P. Optimization approach to depot location and trip selection in one-way carsharing systems. Transp. Res. Part E Logist. Transp. Rev. 2012, 48, 233-247. [CrossRef]

26. Jorge, D.; Correia, G.H.; Barnhart, C. Comparing optimal relocation operations with simulated relocation policies in one-way carsharing systems. IEEE Trans. Intell. Transp. Syst. 2014, 15, 1667-1675. [CrossRef]

27. Barth, M.; Shaheen, S.A. Shared-use vehicle systems: Framework for classifying carsharing, station cars, and combined approaches. Transp. Res. Rec. 2002, 1791, 105-112. [CrossRef]

28. Lewis, A.; Simmons, M. P2P Carsharing Service Design: Informing User Experience Development. Master Thesis, Blekinge Institute of Technology, Karlskrona, Sweden, June 2012.

29. Ballús-Armet, I.; Shaheen, S.A.; Clonts, K.; Weinzimmer, D. Peer-to-peer carsharing: Exploring public perception and market characteristics in the San Francisco Bay area, California. Transp. Res. Rec. 2014, 2416, 27-36. [CrossRef]

30. Nourinejad, M.; Roorda, M.J. Carsharing operations policies: A comparison between one-way and two-way systems. Transportation 2015, 42, 497-518. [CrossRef]

31. Matzner, M.; Chasin, F.; Todenhöfer, L. To Share or Not to Share: Towards Understanding the Antecedents of Participation in IT-Enabled Sharing Services. In Proceedings of the 23rd European Conference on Information Systems, Münster, Germany, 26-29 May 2015.

32. Kortum, K.; Schönduwe, R.; Stolte, B.; Bock, B. Free-floating carsharing: City-specific growth rates and success factors. Transp. Res. Procedia 2016, 19, 328-340. [CrossRef]

33. Verma, M. Growing car ownership and dependence in India and its policy implications. Case Stud. Transp. Policy 2015, 3, 304-310. [CrossRef]

34. Verma, M.; Manoj, M.; Verma, A. Analysis of the influences of attitudinal factors on car ownership decisions among urban young adults in a developing country like India. Transp. Res. Part F 2016, 42, 90-103. [CrossRef]

35. Fukuda, T.; Kashima, S.; Fukuda, A.; Narupiti, S. Analysis of car sharing application on consumer orientation and their modal selection in Bangkok. J. East. Asia Soc. Transp. Stud. 2005, 6, 1971-1986.

36. Kuhnimhof, T.; Buehler, R.; Dargay, J. A new generation: Travel trends for young Germans and Britons. Transp. Res. Rec. 2011, 2230, 58-67. [CrossRef]

37. Hampshire, R.C.; Gaites, C. Peer-to-peer carsharing: Market analysis and potential growth. Transp. Res. Rec. 2011, 2217, 119-126. [CrossRef]

38. Prieto, M.; Baltas, G.; Stan, V. Car sharing adoption intention in urban areas: What are the key sociodemographic drivers? Transport. Res. Part A 2017, 101, 218-227. [CrossRef]

39. Clewlow, R.R. Carsharing and sustainable travel behavior: Results from the San Francisco Bay Area. Transp. Policy 2016, 51, 158-164. [CrossRef]

40. Costain, C.; Ardron, C.; Habib, K.N. Synopsis of users' behaviour of a carsharing program: A case study in Toronto. Transport. Res. Part A 2012, 46, 421-434. [CrossRef]

41. Zheng, J.; Scott, M.; Rodriguez, M.; Sierzchula, W.; Platz, D.; Guo, J.; Adams, T. Carsharing in a university community: Assessing potential demand and distinct market characteristics. Transp. Res. Rec. 2009, 2110 , 18-26. [CrossRef]

42. Gleave, S.D. Carplus Annual Survey of Car Clubs 2016/17; Carplus: London, UK, 2017. Available online: https://como.org.uk/wp-content/uploads/2018/06/Carplus-Annual-Survey-of-Car-Clubs-2016-17London.pdf (accessed on 1 August 2019).

43. Noble, B. Why are some young people choosing not to drive? In Proceedings of the ETC 2005, Strasbourg, France, 18-20 September 2005; Department for Transport: London, UK, 2005.

44. Nordbakke, S.; Ruud, A. Young People and Their Choice of Transport-A Review of Results from Nordic Travel Surveys, Summary in: Tøi Report; Institute of Transport Economics: Oslo, Norway, 2005. Available online: https://www.toi.no/getfile.php/13774/Publikasjoner/T\%C3\%98I\%20rapporter/2005/7602005/summary-final.pdf (accessed on 1 August 2019).

45. Burkhardt, J.E.; Millard-Ball, A. Who is attracted to carsharing? Transp. Res. Rec. 2006, 1986, 98-105. [CrossRef] 
46. Coll, M.H.; Vandersmissen, M.H.; Thériault, M. Modeling spatio-temporal diffusion of carsharing membership in Québec City. J. Transp. Geogr. 2014, 38, 22-37. [CrossRef]

47. Zhou, B.; Kockelman, K.M. Opportunities for and impacts of carsharing: A survey of the Austin, Texas market. Int. J. Sustain. Transp. 2011, 5, 135-152. [CrossRef]

48. Sullivan, E.; Magid, L. Bringing Carsharing to Your Community-Long Guide; City CarShare: San Francisco, CA, USA, 2007.

49. Fujii, S.; Kitamura, R. What does a one-month free bus ticket do to habitual drivers? An experimental analysis of habit and attitude change. Transportation 2003, 30, 81-95. [CrossRef]

50. Ajzen, I. The theory of planned behavior. Organ. Behav. Hum. Dec. 1991, 50, 179-211. [CrossRef]

51. Anable, J. 'Complacent car addicts' or 'aspiring environmentalists'? Identifying travel behaviour segments using attitude theory. Transp. Policy 2005, 12, 65-78. [CrossRef]

52. Handy, S. Methodologies for exploring the link between urban form and travel behavior. Transport. Res. Part D 1996, 1, 151-165. [CrossRef]

53. Steg, L.; Vlek, C.; Slotegraaf, G. Instrumental-reasoned and symbolic-affective motives for using a motor car. Transport. Res. Part F 2001, 4, 151-169. [CrossRef]

54. Kuppam, A.; Pendyala, R.; Rahman, S. Analysis of the role of traveler attitudes and perceptions in explaining mode-choice behavior. Transp. Res. Rec. 1999, 1676, 68-76. [CrossRef]

55. Parkany, E.; Gallagher, R.; Viveiros, P. Are attitudes important in travel choice? Transp. Res. Rec. 2004, 1894, 127-139. [CrossRef]

56. Schaefers, T. Exploring carsharing usage motives: A hierarchical means-end chain analysis. Transport. Res. Part A 2013, 47, 69-77. [CrossRef]

57. Schaefers, T.; Lawson, S.J.; Kukar-Kinney, M. How the burdens of ownership promote consumer usage of access-based services. Market. Lett. 2016, 27, 569-577. [CrossRef]

58. Cullinane, S. The relationship between car ownership and public transport provision: A case study of Hong Kong. Transp. Policy 2002, 9, 29-39. [CrossRef]

59. Zhu, C.; Zhu, Y.; Lu, R.; He, R.; Xia, Z. Perceptions and aspirations for car ownership among Chinese students attending two universities in the Yangtze Delta, China. J. Transp. Geogr. 2012, 24, 315-323. [CrossRef]

60. Morency, C.; Habib, K.M.N.; Grasset, V.; Islam, M.T. Understanding members' carsharing (activity) persistency by using econometric model. J. Adv. Transport. 2012, 46, 26-38. [CrossRef]

61. Barriball, K.L.; While, A. Collecting data using a semi-structured interview: A discussion paper. J. Adv. Nurs. 1994, 19, 328-335. [CrossRef]

62. Longhurst, R. Semi-structured interviews and focus groups. Key Methods Geogr. 2003, 3, 143-156.

63. Rabionet, S.E. How I Learned to Design and Conduct Semi-Structured Interviews: An Ongoing and Continuous Journey. Qual. Rep. 2011, 16, 563-566.

64. Statistics Indonesia. Percentage of Population by Province and Gender. Available online: https://www.bps.go.id/dynamictable/2018/03/20/1288/persentase-penduduk-menurut-provinsi-danjenis-kelamin-2009-2018.html (accessed on 31 May 2019).

65. Statistics Indonesia. Population Projection of Indonesia by Province. Available online: https://www. bps.go.id/statictable/2014/02/18/1274/proyeksi-penduduk-menurut-provinsi-2010---2035.html (accessed on 29 May 2019).

66. Data, Energy, and Modeling Center (EDMC). EDMC Handbook of Energy and Economic Statistics, 2016 ed.; The Energy Conservation Center: Tokyo, Japan, 2016. (In Japanese)

67. World Bank. Population of Indonesia. Available online: https://data.worldbank.org/indicator/SP.POP.TOTL? locations=ID (accessed on 3 June 2019).

68. Greene, W.H.; Hensher, D.A. Modeling Ordered Choices: A Primer; Cambridge University Press: Cambridge, UK, 2010.

69. Erdoğan, S.; Cirillo, C.; Tremblay, J.M. Ridesharing as a green commute alternative: A campus case study. Int. J. Sustain. Transp. 2015, 9, 377-388. [CrossRef]

70. Litman, T. Evaluating carsharing benefits. Transp. Res. Rec. 2000, 1702, 31-35. [CrossRef]

71. Klynveld Peat Marwick Goerdeler (KPMG). Indonesia, High Growth Markets Country Profile. Available online: https://assets.kpmg/content/dam/kpmg/pdf/2015/02/indonesia-hgm.pdf (accessed on 3 June 2019). 
72. Deloitte. Deloitte Consumer Insights-The Evolution of the Indonesia Consumer. Available online: https://www2.deloitte.com/content/dam/Deloitte/jp/Documents/consumer-business/cp/jp-cp-ci2016idneng-1227.PDF (accessed on 3 June 2019).

73. Cronbach, L.J. Coefficient alpha and the internal structure of tests. Psychometrika 1951, 16, 297-334. [CrossRef]

74. World Bank. Individuals Using the Internet in Indonesia in 2017. Available online: https://data.worldbank. org/indicator/IT.NET.USER.ZS?locations=ID (accessed on 28 May 2019).

(c)

(C) 2019 by the authors. Licensee MDPI, Basel, Switzerland. This article is an open access article distributed under the terms and conditions of the Creative Commons Attribution (CC BY) license (http://creativecommons.org/licenses/by/4.0/). 